\title{
Possible threshold controls on sediment grain properties of Peruvian coastal river basins
}

\author{
Camille Litty ${ }^{1}$, Fritz Schlunegger ${ }^{1}$, and Willem Viveen ${ }^{2}$ \\ ${ }^{1}$ Institute of Geological Sciences, University of Bern, Baltzerstrasse 1 + 3, 3012 Bern, Switzerland \\ ${ }^{2}$ Grupo de Investigación en Geología Sedimentaria, Sección de Ingeniería de Minas, Departamento de \\ Ingeniería, Pontificia Universidad Católica del Perú, Av. Universitaria 1801, San Miguel, Lima, Peru \\ Correspondence to: Camille Litty (camille.litty@geo.unibe.ch)
}

\author{
Received: 9 February 2017 - Discussion started: 1 March 2017 \\ Revised: 4 August 2017 - Accepted: 12 August 2017 - Published: 18 September 2017
}

\begin{abstract}
To determine possible controls on sediment grain properties, 21 coastal rivers located along the entire western Peruvian margin were analysed. This represents one of the largest grain size dataset that has been collected over a large area. Modern gravel beds were sampled along a north-south transect on the western side of the Peruvian Andes where the rivers cross the tip of the mountain range, and at each site the long $a$ axis and the intermediate $b$ axis of about 500 pebbles were measured. Morphometric properties of each drainage basin, sediment and water discharge, together with flow shear stresses, were determined and compared against measured grain properties. Pebble size data show that the values for the $\mathrm{D}_{50}$ are nearly constant and range between 2 and $3 \mathrm{~cm}$, while the values of the $\mathrm{D}_{96}$ range between 6 and $12 \mathrm{~cm}$. The ratios between the intermediate and the long axis range from 0.67 to 0.74 . Linear correlations between all grain size percentiles and water shear stresses, mean basin denudation rates, mean basin slopes and basin sizes are small to non-existent. However, exceptionally large $\mathrm{D}_{50}$ values of 4-6 cm were measured for basins situated between 11-12 and 16-17 $\mathrm{S}$ latitude where hillslope gradients are steeper than on average or where mean annual stream flows exceed the average values of the western Peruvian streams by a factor of 2 . We suggest that the generally uniform grain size pattern has been perturbed where either mean basin slopes or water fluxes exceed threshold conditions.
\end{abstract}

\section{Introduction}

The size and shape of gravels bear crucial information about (i) the transport dynamics of mountain rivers (Hjulström, 1935; Shields, 1936; Blissenbach, 1952; Koiter et al., 2013; Whittaker et al., 2007; Duller et al., 2012; Attal et al., 2015), (ii) the mechanisms of sediment supply and provenance (Parker, 1991; Paola et al., 1992a, b; Attal and Lavé, 2006), and (iii) environmental conditions such as uplift and precipitation (Heller and Paola, 1992; Robinson and Slingerland, 1998; Foreman et al., 2012; Allen et al., 2013; Foreman, 2014). The mechanisms by which grain size and shape change from source to sink have often been studied with flume experiments (e.g. McLaren and Bowles, 1985; Lisle et al., 1993) and numerical models (Hoey and Ferguson, 1994). These studies have mainly been directed towards exploring the controls on the downstream reduction in grain size of gravel beds (Schumm and Stevens, 1973; Hoey and Fergusson, 1994; Surian, 2002; Fedele and Paola, 2007; Allen et al., 2016). In addition, it has been proposed that the grain size distribution, particularly of mountainous rivers, mainly depends on (i) tectonic uplift resulting in steepening of the entire landscape (Dadson et al., 2003; Wittmann et al., 2007; Ouimet et al., 2009), (ii) earthquakes and seismicity causing the release of large volumes of landslides (Dadson et al., 2003; McPhillips et al., 2014), (iii) precipitation rates and patterns controlling river discharge and shear stresses (D'Arcy et al., 2017; Litty et al., 2017), and (iv) bedrock lithology in which low erodibility lithologies are sources of larger volumes of material (Korup and Schlunegger, 2009; Allen et al., 2015). Accordingly, the sediment caliber in these rivers could reflect the nature of erosional processes in the headwaters and conditions thereof (such as lithology, slope 
angles, seismicity releasing landslides), which then correspond to supply-limited conditions. Alternatively, if enough material is supplied to the streams, then the grain size pattern mainly depends on the run-off and related shear stresses in these rivers, which in turn correspond to transport-limited conditions.

The western margin of the Peruvian Andes represents a prime example of where these mechanisms and related controls on the grain size distribution of river sediments can be explored. In particular, this mountain belt has experienced intense and frequent earthquakes (Nocquet et al., 2014) in response to subduction of the oceanic Nazca plate beneath the continental South American plate at least since late Jurassic times (Isacks, 1988). Therefore, it is not surprising that erosion and the transfer of material from the hillslopes to the rivers has been considered to strongly depend on the occurrence of earthquakes (McPhilipps et al., 2014). Conversely, it has also been proposed that denudation in this part of the Andes is controlled by distinct precipitation rate gradients. These inferences have been made based on concentrations of in situ cosmogenic ${ }^{10} \mathrm{Be}$ measured in river-borne quartz (Abbühl et al., 2011; Carretier et al., 2015; Reber et al., 2017) and on morphometric analyses of the western Andean landscape (Montgomery et al., 2001). Accordingly, erosion along the western Peruvian Andes has been related to either the occurrence of earthquakes and thus tectonic processes (McPhillips et al., 2014) or rainfall rates (Abbühl et al., 2011; Carretier et al., 2015) and to the stream's mean annual run-off and thus climatic processes (Reber et al., 2017). Therefore, we hypothesize that hillslope erosion paired with the stream runoff is likely to have a measurable impact on the grain size pattern in the Peruvian streams.

Here we present data on sediment grain properties from rivers situated on the western margin of the Peruvian Andes (Fig. 1a) in order to elucidate the possible effects of intrinsic factors, such as morphometric properties of the drainage basins (mean slope, drainage area, stream lengths), and extrinsic properties (run-off and seismic activity) on sediment grain properties. Thus, we collected grain size data from gravel bars of each stream along the entire western Andean margin of Peru that derived from large basins over $700 \mathrm{~km}^{2}$. Sampling sites were situated at the outlets of valleys close to the Pacific coast. This represents one of the largest grain size datasets that has ever been collected over areas that have experienced different tectonic and climatic conditions.

\subsection{Geologic and tectonic setting}

The study area is located at the transition from the Peruvian Andes to the coastal lowlands along a transect from the cities of Trujillo in the north $\left(8^{\circ} \mathrm{S}\right)$ to Tacna in the south $\left(18^{\circ} \mathrm{S}\right)$. In northern and central Peru, a flat, broad coastal forearc plain up to $100 \mathrm{~km}$ wide with Paleogene-Neogene and Quaternary sediments connects to the western Cordillera. This part of the western Cordillera consists of Cretaceous to late
Miocene plutons of various compositions (diorite, but also tonalite, granite and granodiorite) that crop out over an almost continuous, $1600 \mathrm{~km}$ long arc that is referred to as the Coastal Batholith (e.g. Atherton, 1984; Mukasa, 1986; Haederle and Atherton, 2002; Fig. 1b). In southern Peru, the coastal plain gives way to the Coastal Cordillera that extends far into Chile. The western Cordillera comprises the central volcanic arc region of the Peruvian Andes with altitudes of up to $6768 \mathrm{~m}$ a.s.l., where currently active volcanoes south of $14^{\circ} \mathrm{S}$ of latitude are related to a steep slab subduction. Conversely, Cenozoic volcanoes in the central and northern Peruvian arc have been extinct since c. $11 \mathrm{Ma}$ due to a flat slab subduction, which inhibited magma upwelling from the asthenosphere (Ramos, 2010).

The bedrock of the western Cordillera is dominated by Paleogene, Neogene and Quaternary volcanic rocks (mainly andesitic or dacitic tuffs and ignimbrites) originating from distinct phases of Cenozoic volcanic activity (Vidal, 1993). These rocks rest on Mesozoic and early Paleogene sedimentary rocks (Fig. 1b).

The tectonic conditions of the western Andes are characterized by strong N-S gradients in Quaternary uplift, seismicity and long-term subduction processes, which in turn seem controlled by a plethora of tectonic processes. The northern segment of the coastal Peruvian margin (i.e. to the north of $13^{\circ} \mathrm{S}$ latitude) hosts a coastal plain that shows little evidence for uplift, and the Nazca plate subducts at a low angle. Also in this region, the occurrence of large historical earthquakes at least along the coastal segment has been much less frequent (Fig. 2c). Only in northernmost Peru (4 to $6^{\circ} \mathrm{S}$ latitude) is uplift of the coastal area associated with subduction-induced earthquakes (Bourgois et al., 2007). Further south, the Cordillera Blanca area (around $12^{\circ} \mathrm{S}$ latitude) may have been uplifted due to upwelling of magma (McNulty and Farber, 2002). In particular, the coastal segment south of $13^{\circ} \mathrm{S}$ hosts raised Quaternary marine terraces (Regard et al., 2010), suggesting the occurrence of surface uplift at least during Quaternary times. Since the number and altitude of the terraces increases closer to the area where the Nazca ridge currently subducts, uplift of the coastal area in a radius of approximately $200 \mathrm{~km}$ around the ridge (roughly 12 to $14^{\circ} \mathrm{S}$ latitude) is attributed to ridge subduction (Sébrier et al., 1988; Macharé and Ortlieb, 1992). Between 15 and $18^{\circ} \mathrm{S}$ latitude, uplift is associated with bending of the Bolivian orocline (Noury et al., 2016). The area south of $12^{\circ} \mathrm{S}$ latitude is also the segment of the Andes in which the number of earthquakes with magnitudes $>4$ has been larger relative to the segment farther north (Figs. 1 and 2c). In contrast, the northern segment of the coastal Peruvian margin (i.e. to the north of $13^{\circ} \mathrm{S}$ latitude) hosts a coastal plain that has been subsiding and the Nazca plate subducts at a low angle. Also in this region, the frequency of large historical earthquakes, at least along the coastal segment, has been much less (Fig. 2c) 


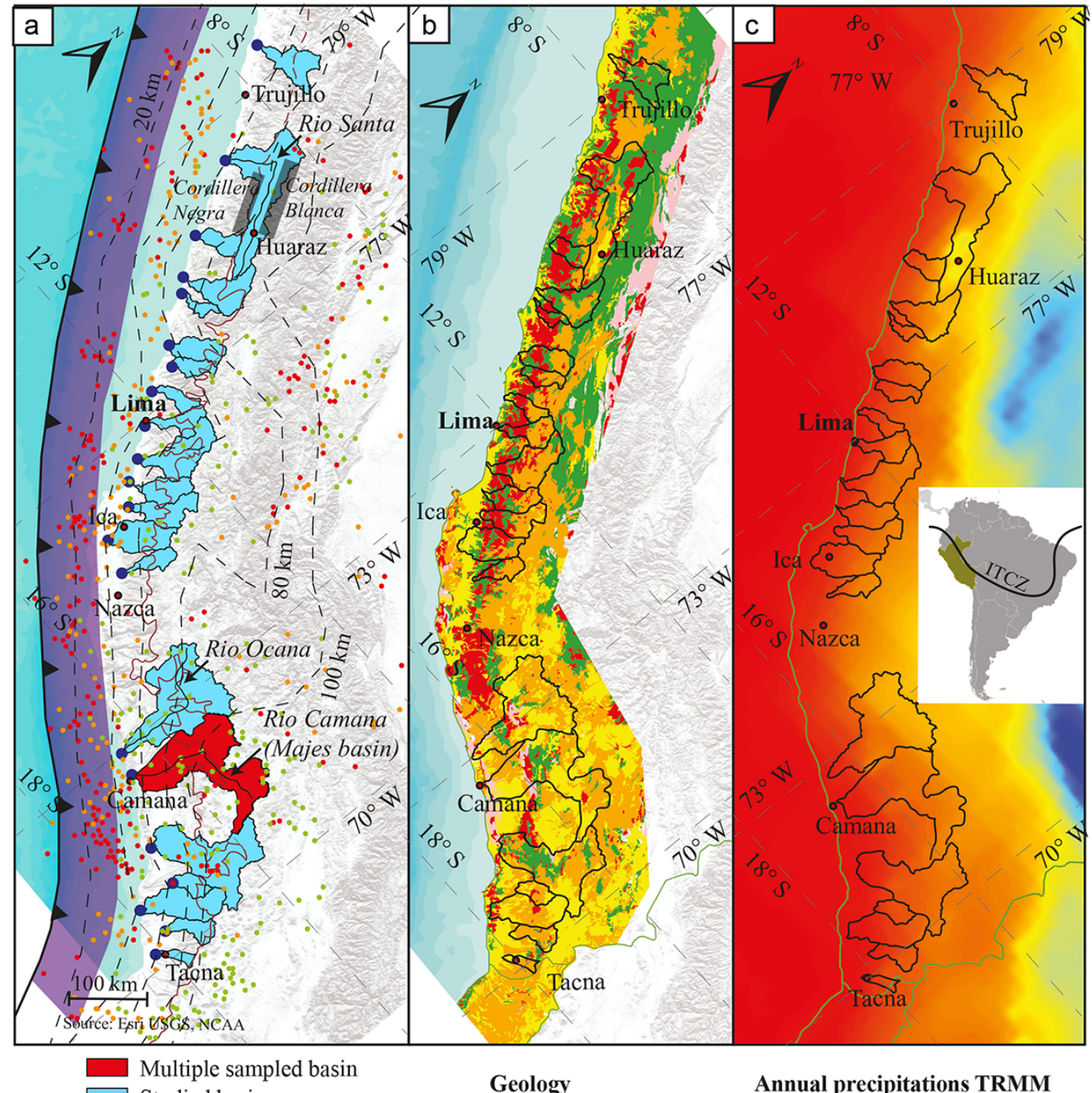

- Sampling site • City

USGS earthquake archive (Mag > 4.5)

Depth $(\mathrm{km}) \bullet 0-33$

- $33-70$

- $70-300$

A Trench axis
Quaternary deposits

Cenozoic rocks

Coastal Batholith

Mesozoic rocks

Metamorphic rocks
Annual precipitations TRMM

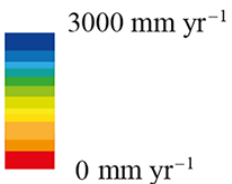

Figure 1. (a) Map of the studied basins showing the sampling sites and the western escarpment (western escarpment modified after Trauerstein et al., 2013). The purple strip east of the trench axis corresponds to the swath over which the historical earthquake data, presented in Fig. 2. The map also illustrates the location of the buoyant Nazca ridge, depth of the slab as a dashed line, and patterns of earthquake occurrence. (b) Geological map of the western Peruvian Andes. (c) Map of the precipitation rates showing the spatial extent of the ITCZ, modified after Huffman et al. (2007).

\subsection{Morphological setting}

The local relief along the western Cordillera has been formed by deeply incising rivers that flow perpendicular to the strike of the Andes (Schildgen et al., 2007). The morphology of the longitudinal stream profiles is characterized by two segments separated by a distinct knickzone (Trauerstein et al., 2013). These geomorphic features have formed through headward retreat in response to a phase of enhanced surface uplift dur- ing the late Miocene (e.g. Schildgen et al., 2007). Upstream of these knickzones, the streams are mainly underlain by Cenozoic volcaniclastic rocks, while farther downstream incision has disclosed the Coastal Batholith and older metasedimentary units (Trauerstein et al., 2013). The upstream edges of these knickzones also delineate the upper boundary of the major sediment sources (Litty et al., 2017). Little to nearly zero clastic material is derived from the headwa- 


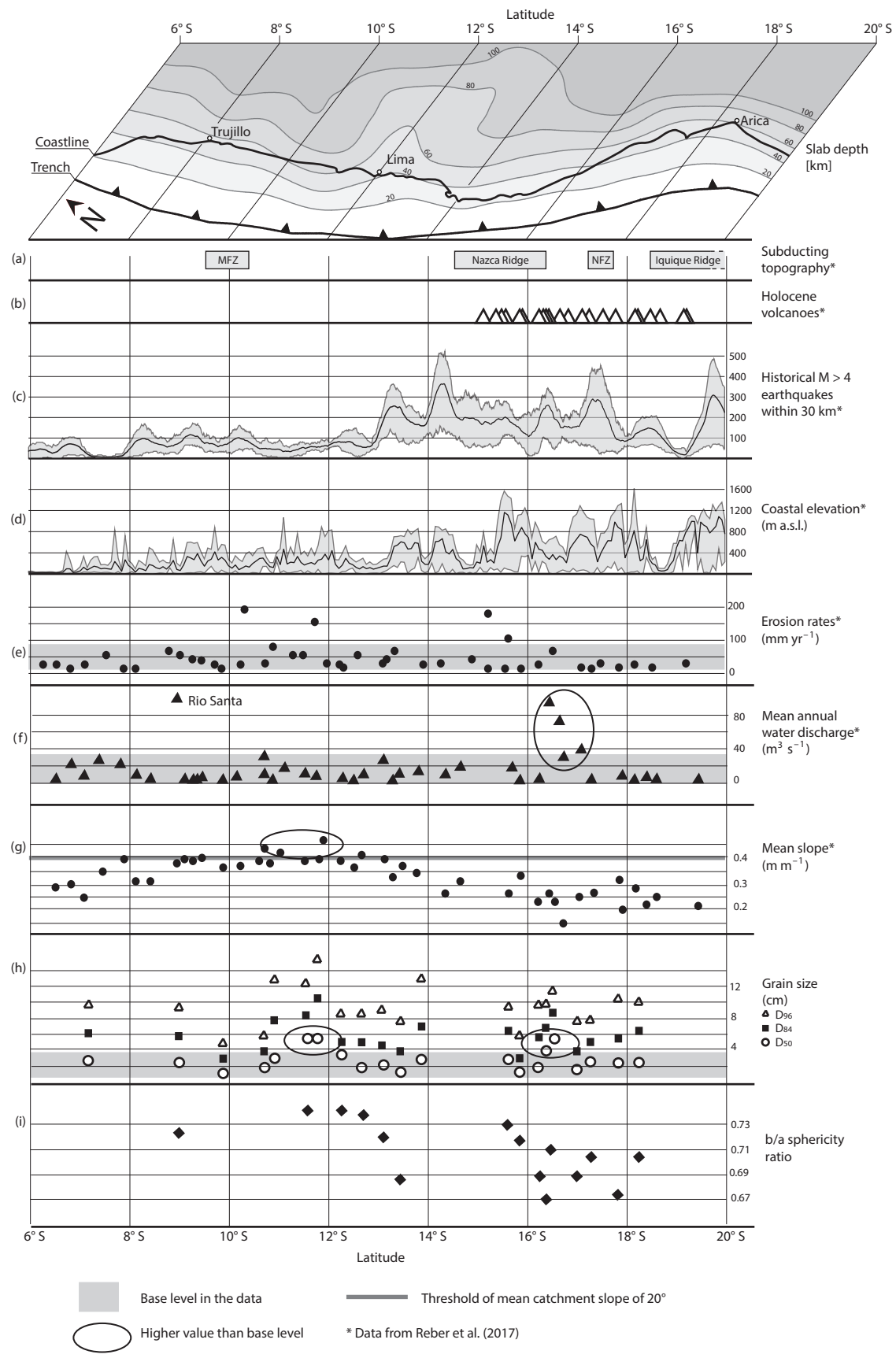

Figure 2. Topography of the subducting Nazca plate, where slab depth data have been extracted from http://earthquake.usgs.gov/data/slab/ modified from Reber et al. (2017). This N-S projection also illustrates (a) tectonic lineaments such as submarine ridges, MFZ: Mendaña fracture zone, NFZ: Nazca fracture zone, (b) Holocene volcanoes, (c) earthquake data taken from http://earthquake.usgs.gov/earthquakes/search/ , number of earthquakes with $M>4$ within a $30 \mathrm{~km}$ radius window and (d) coastal elevation. The data have been extracted from a $20 \mathrm{~km}$ wide swath along the coast. The three lines represent maximum, mean and minimum elevations within the selected swath. (e) Catchment averaged denudation rates have been corrected for quartz contents (Reber et al., 2017). (f) Mean annual precipitation rates (Reber et al., 2017). (g) Mean annual water discharge (Reber et al., 2017). (h) Grain size results for the intermediate $b$ axis of the pebbles in the rivers from north to south at the sampling sites presented in Fig. 1. (i) Ratio between the intermediate axis and the long $a$ axis (modified after Reber et al., 2017). Exceptionally larger $D_{50}$ values of $4-6 \mathrm{~cm}$ were measured for basins situated between $11-12$ and $16-17^{\circ} \mathrm{S}$, where hillslope gradients are steeper than 0.4 on average (i.e. $20-22^{\circ}$ ) or where mean annual stream flows exceed the average values of the western Peruvian streams $\left(10-40 \mathrm{~m}^{3} \mathrm{~s}^{-1}\right)$ by a factor of 2 . 
ter reaches on the Altiplano, where the flat landscape experiences nearly zero erosion, as ${ }^{10} \mathrm{Be}$-based denudation rate estimates (Abbühl et al., 2011) and provenance tracing have shown (Litty et al., 2017).

The pattern of mean slopes per drainage basin reveals a distinct $\mathrm{S}-\mathrm{N}$ trend (Table 1 ). The corresponding values increase from 20 to $25^{\circ}$ going from 6 to $10^{\circ} \mathrm{S}$ latitude (where they reach maximum values between 0.4 and $0.45 \mathrm{~m} \mathrm{~m}^{-1}$ ) after which they decrease by nearly $50 \%$ to values ranging between 10 and $15^{\circ}$ further north. These relationships have not been explored yet but most likely reflect the extent to which streams have crossed the western escarpment and sourced their waters in the relatively flat plateau of the Puna region. Indeed, most of the western Peruvian streams have their water sources on this flat area and then cross the western escarpment, which yields relatively low mean basin slopes particularly for basins south of $12^{\circ} \mathrm{S}$. Conversely, the basins around $11-12^{\circ} \mathrm{S}$ latitudes (which are characterized by the steep slopes) have their sources in the relatively steep Cordillera Negra (Fig. 1a), which is a relatively dry mountain range situated on the steep escarpment. Along these latitudes, the high Andes are constituted by the high and heavily glaciated Cordillera Blanca situated farther to the east (Fig. 1a). This mountain range is drained by the Rio Santa, which flows parallel to the Andes strike and then crosses the Cordillera Negra at a right angle (Fig. 1a).

\subsection{Climatic setting and stream run-off}

The Peruvian western margin shows an E-W contrasting precipitation pattern with high annual precipitation rates of up to $800 \mathrm{~mm}$ on the Altiplano and ca. $0 \mathrm{~mm}$ per year on the coast (Huffman et al., 2007; Fig. 1c in this paper). This precipitation gradient in the western Andes is related to the position of the Intertropical Convergence Zone (ITCZ, inset of Fig. 1c) associated with an orographic effect on the eastern side of the Andes (Bookhagen and Strecker, 2008). During austral summer (January) the centre of the ITCZ is located farther south, transferring the moisture from the Amazon tropical basin to the Altiplano (Garreaud et al., 2009) and leading to a wet climate on the Altiplano with high precipitation rates. During austral winter, the Altiplano is under the influence of dry air masses from the subsiding branch of the Hadley cell that result in a more equatorial position of the ITCZ and in a dry persistent westerly wind with almost no precipitation on the Altiplano. Additionally, the Andes form an orogenic barrier preventing Atlantic winds and moisture from reaching the coast. In addition, every 2 to 10 years, near the Equator, the Pacific coast is subjected to strong precipitation related to the El Niño weather phenomenon and resulting in high flood variability (DeVries, 1987).

Mean annual discharge of streams along the western Peruvian margin has been reported by Reber et al. (2017). These authors calculated mean annual discharge values using the TRMM-V6.3B43.2 precipitation database by Huffman et 
al. (2007) as a basis. Reber et al. (2017; see their Table 3) corrected the theoretical values for water losses due to evaporation and irrigation using the gauging record of a minimum of 12 basins situated close to the Pacific Ocean. For these areas, hydrological data have been reported by the Sistema Nacional de Información de Recursos Hídricos (SNIRH, 2017). The hydrological data thus cover a time span of ca. 12 years. The results show a pattern in which mean annual run-off of these streams ranges between ca. 10 and $40 \mathrm{~m}^{3} \mathrm{~s}^{-1}$. Rivers in which mean annual run-off values are nearly $80 \mathrm{~m}^{3} \mathrm{~s}^{-1}$ comprise the Rio Santa at ca. $9^{\circ} \mathrm{S}$ latitude (Fig. 1a), which derives its water from glaciers in the Cordillera Blanca. Two other streams with high discharge values are situated at $16-17^{\circ} \mathrm{S}$ (Rio Ocoña and Rio Camaña, Fig. 1a), where the corresponding headwaters spread over a relatively large area across the Altiplano, thereby collecting more rain than the other basins.

\section{Site selection and methods}

Sampling sites are situated in the main river valleys in the western Cordillera between 8 and $18^{\circ} \mathrm{S}$ latitude just before it gives way to the coastal margin. We selected 21 river basins larger than $700 \mathrm{~km}^{2}$. We selected the downstream end of these rivers for simplicity and because this yields comparable conditions as the base level is the same for all streams. Sampling sites are all accessible along the Pan-American Highway (see Table 1 for the coordinates of the sampling sites). Additionally, the Majes basin (marked with red in Fig. 1a) has been sampled at five sites from upstream to downstream to explore the effects related to the sediment transport processes for a section across the mountain belt, but along the stream (Fig. 3, Table 2). The Majes basin has been chosen because of its easy accessibility in the upstream direction and because the morphology of this basin has been analysed in a previous study (Steffen et al., 2010).

At each sampling site, we randomly selected five longitudinal bars where we collected our grain size dataset. It has been shown that using a standard frame with fixed dimensions to assist gravel sampling reduces user-biased selections of gravels (Marcus et al., 1995; Bunte and Abt, 2001a). In order to reduce this bias, we substituted the frame by shooting an equal number of photos at a fixed distance (ca. $1 \mathrm{~m}$ ) from the ground surface at each longitudinal bar. From an approximately $10 \mathrm{~m}^{2}$ large area, 10 photos were taken to take potential spatial variabilities among the gravel bars into account. From those photos, the intermediate $b$ axis and the ratio of the $b$ axis and the long $a$ axis of around 500 randomly chosen pebbles were manually measured (Bunte and Abt, 2001b) and processed using the software program ImageJ (Rasband, 1997). Our sample population exceeds the minimum number of samples needed for statistically reliable estimations of grain size distributions in gravel bars (Howard, 1993; Rice and Church, 1998).

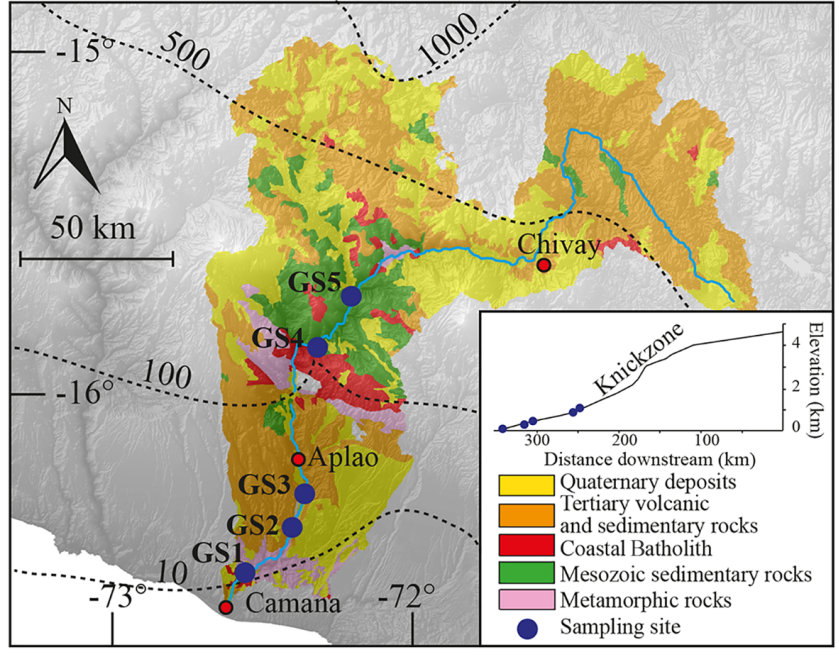

Figure 3. Geological map of the Majes basin overlain by the precipitation pattern (precipitation data from Steffen et al., 2010), in which the black dashed lines show precipitation rates $\left(\mathrm{mm} \mathrm{yr}^{-1}\right)$. GS1 to GS5 represent sites where grain size data have been collected. The right corner shows the Majes river long profile.

The pebbles were characterized on the basis of their median $\left(\mathrm{D}_{50}\right)$, the $\mathrm{D}_{84}$ and the coarse $\left(\mathrm{D}_{96}\right)$ fractions. This means that 50,84 and $96 \%$ of the sampled fraction is finer grained than the 50th, 84th and 96th percentiles of the samples. On a gravel bar, pebbles tend to lie with their short axis perpendicular to the surface, thus exposing their section that contains the $a$ and $b$ axes (Bunte and Abt, 2001b). However, the principal limitation is the inability to accurately measure the fine particles $<3 \mathrm{~mm}$ (see also Whittaker et al., 2010). While we cannot resolve this problem with the techniques available, we do not expect that this adds a substantial bias in the grain size distributions reported here as their relative contributions to the point count results are minor (i.e. $<5 \%$, based on visual inspection of the digital images).

Catchment-scale morphometric parameters and characteristics, including drainage area, mean slope angle for each catchment, slope angle of the stream channel at the sampling site and distances from the sampling sites to the upper edge of the western escarpment, were extracted from the $90 \mathrm{~m}$ resolution DEM Shuttle Radar Topography Mission (SRTM; Reuter et al., 2007).

Because grain size pattern largely depends on water shear stresses, we explored the possible correlations between water shear stresses and grain size distribution. We thus computed water shear stresses $\tau$ following Hancock and Anderson (2002) and Litty et al. (2016), in which:

$\tau=0.54 \rho g\left(\frac{Q}{W}\right)^{0.55} S^{0.93}$.

Here, $\rho=1000 \mathrm{~kg} \mathrm{~m}^{-3}$ is the water density, $g$ the gravitational acceleration, $Q\left(\mathrm{~m}^{3} \mathrm{~s}^{-1}\right)$ the mean annual water 
Table 2. Location of the sampling sites in the Majes basin and grain size results in the Majes basin.

\begin{tabular}{lrrrr|rrrr}
\hline & $\begin{array}{r}\text { Distance from } \\
\text { the coast }(\mathrm{km})\end{array}$ & $\begin{array}{r}\text { Altitude } \\
(\mathrm{m})\end{array}$ & $\begin{array}{r}\text { Latitude } \\
\left({ }^{\circ}, \text { WGS84 }\right)\end{array}$ & $\begin{array}{r}\text { Longitude } \\
\left({ }^{\circ}, \text { WGS84 }\right)\end{array}$ & D $_{50}$ & $\mathrm{D}_{84}$ & $\mathrm{D}_{96}$ & $b / a$ \\
\hline GS1 & 20 & 69 & -16.51 & -72.64 & 5.2 & 8.7 & 11.6 & 0.67 \\
GS2 & 45 & 283 & -16.37 & -72.49 & 4.8 & 10 & 15 & 0.69 \\
GS3 & 57 & 378 & -16.28 & -72.45 & 5.4 & 12.7 & 21 & 0.65 \\
GS4 & 90 & 700 & -16.00 & -72.48 & 3.3 & 12 & 22.5 & 0.67 \\
GS5 & 106 & 882 & -15.86 & -72.45 & 6.2 & 19 & 31 & 0.71 \\
\hline
\end{tabular}

discharge that we have taken from Reber et al. (2017), $W$ (m) the channel width, and $S\left(\mathrm{~m} \mathrm{~m}^{-1}\right)$ the channel gradient. Stream channel widths with an estimated error of $2 \mathrm{~m}$ were measured on satellite images where available and on photos taken during the field campaign.

We were also interested in exploring whether sediment flux has a measurable impact on the grain size pattern because higher denudation rates could be associated with the supply of more coarse-grained material to the trunk stream. This in turn could result in larger clasts in these streams and could potentially cause gravel fronts to shift towards more distal sites (Dingle et al., 2017), thereby coarsening the sediment caliber at our sampling sites. These basins have recently been analysed for denudation rates averaged by mean ${ }^{10} \mathrm{Be}-$ based catchments and annual water fluxes (please see Reber et al., 2017, and information presented above). This allows us to explore whether sediment flux, which equals the product between ${ }^{10} \mathrm{Be}$-based denudation rates and basin size, has a measurable impact on the grain size pattern.

Possible covariations and correlations between grain size and/or morphometric parameters and basin characteristics were evaluated using Pearson correlation coefficients, thus providing corresponding $r$ values (Table 3). The $r$ values measure the linear correlations between variables. The values range between +1 and -1 , in which +1 reflects a $100 \%$ positive linear correlation, 0 reflects no linear correlation and -1 indicates a $100 \%$ negative linear correlation (Pearson, 1895). Threshold values of $>+0.30$ and $<-0.30$ were selected to assign positive and negative correlations, respectively.

\section{Results}

\subsection{Grain size}

The results of the grain size measurements reveal a large variation in the $b$ axis. The $\mathrm{D}_{50}$ values range from 1.3 to $5.5 \mathrm{~cm}$ (Fig. 2h, Table 1). Likewise, $\mathrm{D}_{84}$ values vary between 3 and $10.5 \mathrm{~cm}$. The sizes for the $\mathrm{D}_{96}$ reveal the largest spread, ranging from 6 to $31 \mathrm{~cm}$. The ratio between the $b$ axis and $a$ axis (sphericity ratio) is nearly constant and varies between 0.67 and 0.74 (Fig. 2i). Note that between 15.6 and $13.7^{\circ} \mathrm{S}$, no gravel bars are encountered in the rivers where they leave the mountain range, and only sand bars can be found. Therefore, no results are exhibited for these latitudes (Fig. $2 \mathrm{~h}$ and i).

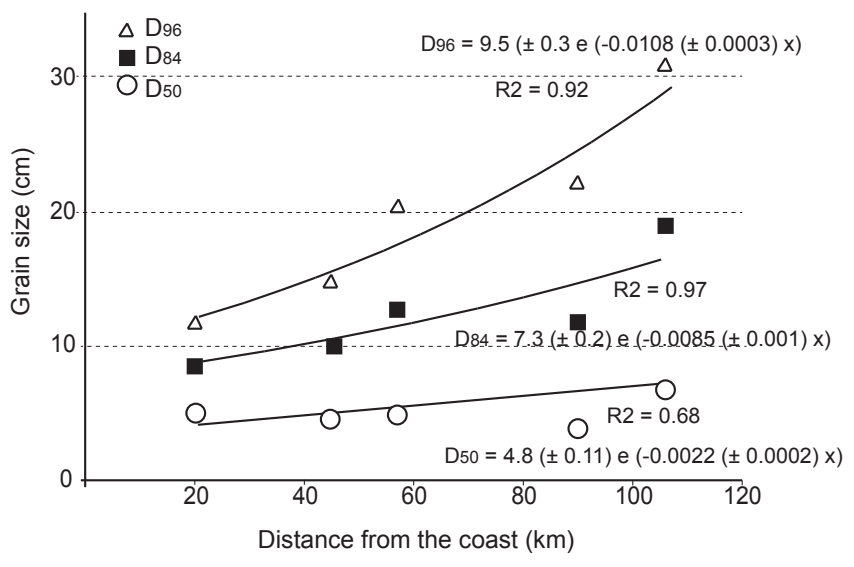

Figure 4. Grain size results along the Majes River.

\subsection{The Majes basin}

The $\mathrm{D}_{50}$ percentile of the $b$ axis decreases from $6.2 \mathrm{~cm}$ to a value of $5.2 \mathrm{~cm}$ ca. $80 \mathrm{~km}$ farther downstream (Figs. 3 and 4 and Table 2). Likewise, the $\mathrm{D}_{84}$ decreases from 19 to $8.7 \mathrm{~cm}$, and the $\mathrm{D}_{96}$ decreases from 31 to $11.6 \mathrm{~cm}$ (Fig. 4). Geomorphologists widely accept the notion that the downstream hydraulic geometry of alluvial channels reflects the decrease in particle size within an equilibrated system involving stream flow, channel gradient, sediment supply and transport (Hoey and Ferguson, 1994; Fedele and Paola, 2007; Attal and Lavé, 2009). Sternberg (1875) formalized these relations and predicted an exponential decline in particle size in gravel-bed rivers as a consequence of abrasion and selective transport where the gravel is transported downstream. The relation follows the form: $D_{x}=D_{0} e^{-\alpha x}$ (Sternberg, 1875). Here, the three percentiles follow an exponential fining decrease with the exponent $\alpha$ ranging from 0.3 for the $\mathrm{D}_{96}$ to 0.1 for the $\mathrm{D}_{50}$ (Fig. 4).

\subsection{Correlations between grain sizes and morphometric properties}

Table 3 shows the Pearson correlation coefficients ( $r$ value) between the grain sizes, the morphometric parameters and the characteristics of the basins. As was expected, the $\mathrm{D}_{50}, \mathrm{D}_{84}$ and $\mathrm{D}_{96}$ all strongly correlate with each other 


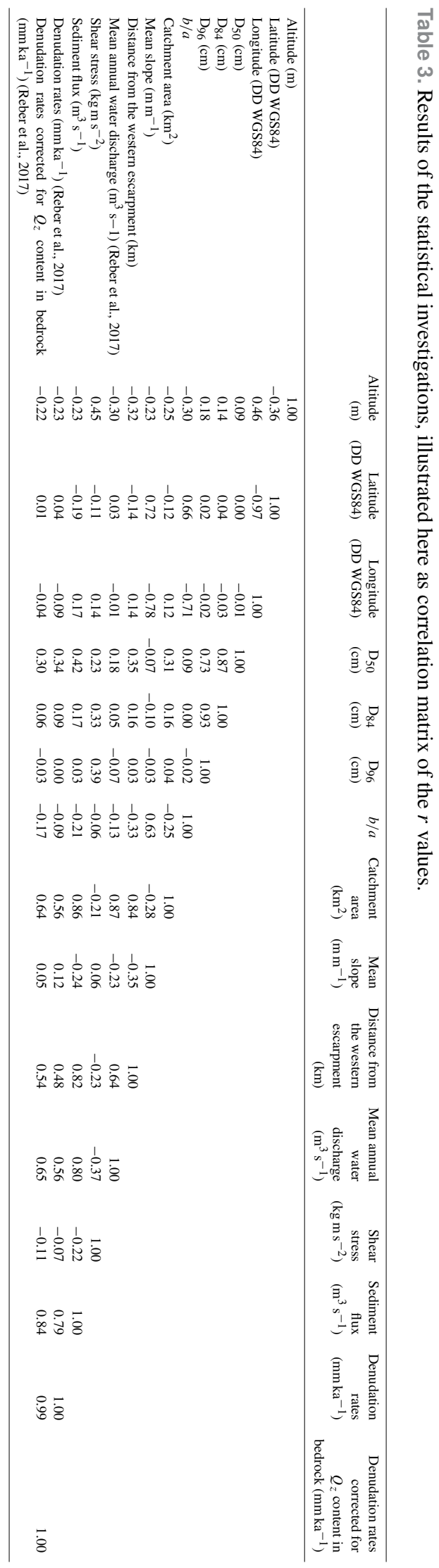

$(0.73<r$ value $<0.93)$, but the $b / a$ ratios do not correlate with any of the three percentiles $(-0.1<r$ value $<0.1)$. Likewise, inter-correlation relationships also exist among other variables such as catchment area, distance from the western escarpment, sediment flux and water discharge (Table 3 ). The $\mathrm{D}_{50}$ values positively but weakly correlate with the sizes of the catchment area $(r$ value $=0.31)$, the distances from the western escarpment ( $r$ value $=0.35$ ), the mean annual shear stresses at the sampling site $(r$ value $=0.23)$, the denudation rates $(r$ value $=0.34)$ and the sediment fluxes $(r$ value $=0.42$; Table 3$)$. The $\mathrm{D}_{84}$ and the $\mathrm{D}_{96}$ values of the grain size data correlate positively with the mean annual shear stresses exerted by the water flux, with relative low $r$ value of 0.33 and 0.39 (Table 3).

On a broader scale, values of the $\mathrm{D}_{50}$ are nearly constant between 2 and $3 \mathrm{~cm}$ (Table 3 ). The largest $D_{50}$ values of up to $6 \mathrm{~cm}$ are encountered in streams that are either sourced in the Cordillera Negra, where mean basin slope angles are larger than $20^{\circ}$, or in the Rio Ocoña and Rio Camaña rivers located at $16-17^{\circ} \mathrm{S}$, which have the largest mean annual discharge as they capture their waters from a broad area on the Altiplano.

The ratio of the intermediate axis over the long axis negatively correlates with the distance from the western escarpment $(r$ value $=-0.33)$, albeit with a poor correlation, but a strong positive correlation is found with the mean slope angles of the basins ( $r$ value $=0.63$; Table 3 ).

\section{Discussion}

\subsection{Slope angle controls on sphericity}

The poor negative correlation of -0.33 between the sphericity of the pebbles and distance from the escarpment edge (Table 3) prevents us from inferring a distinct control of this variable. Conversely, the positive Pearson correlation of 0.63 between the sphericity of the pebbles and the mean basin slope is quite high (Table 3), thus pointing towards a significant control. This suggests that basins with steeper slopes produce rounder pebbles. We do not consider that this pattern is due to differences in exposed bedrock in the hinterland because the litho-tectonic architecture is fairly constant along the entire Peruvian margin (Fig. 1). We tentatively infer that timescales of transport and evacuation of material are likely to be shorter in steeper basins compared to shallower ones. This might influence the shape of pebbles as they tend to flatten due to abrasion and 3-D heterogeneities of bedrock, which becomes more obvious with time and transport distance (Sneed and Folk, 1958). We thus see the positive correlation between mean basin hillslope angle and the sphericity of pebbles as a very likely consequence of shorter transport times in steeper basins, but we note that this hypothesis needs to be confirmed by detailed real-time surveys of material transport from sources down to the end of these rivers. 


\subsection{Controls on grain size}

\subsubsection{Downstream fining trends in the Majes basin indicate fluvial controls}

In fluvial environments, the sorting of the sediment depends on the downstream distance from its source (Hoey and Ferguson, 1994; Kodoma, 1994; Paola and Seal, 1995). This is particularly the case for the Majes river, where we see an exponential downstream fining trend (Fig. 4). This is somewhat surprising because sufficiently voluminous sediment input from other sources may perturb any downstream fining trends in the grain size distribution (Rice and Church, 1998). Likewise, in the Majes basin, the sediment supply from the hillslopes to the trunk stream has occurred mainly through debris flow processes and landsliding (Steffen et al., 2010; Margirier et al., 2015). Thus, while the supply of hillslopederived material is likely to have been accomplished by mass wasting processes, its imprint on grain size appears to be modified by the evacuation and the transport of this sediment down to the Pacific Ocean through fluvial transport.

\subsubsection{Grain size and earthquake impact}

Landslides and debris flows represent the main processes of hillslope erosion and the main sources of sediment in tectonically active orogens (Hovius et al., 1997; Korup and Weidinger, 2011). They are generally associated with triggers such as earthquakes or intense rainfall and generally supply coarse and voluminous sediments to the trunk rivers (Dadson et al., 2003; McPhillips et al., 2014). In that sense, we would expect a positive correlation between the frequency of large earthquakes and the grain size, in which an increase in earthquake frequency would induce an increase in landslide occurrence, thereby supplying coarser grained sediment from the hillslopes to the rivers. These relationships have been elaborated on in multiples studies in which positive relationships between landslide occurrence and the size of earthquakes have been documented (e.g. Keefer, 1984, 1994; Parker et al., 2011). We note that a global-scale correlation between earthquake magnitudes and areas affected by landslides suggests that mass movements are triggered by earthquakes if a threshold magnitude of 5.5 is exceeded (Keefer, 1984). Here, we consider earthquakes with magnitudes $>4.5$ because Fig. 1 by Keefer (1984) suggests that earthquakes with magnitudes as low as 4.5 are theoretically able to release landslides over an area larger than $10 \mathrm{~km}^{2}$. However, we do not see correlation between the number of recorded historical earthquakes larger than $4.5 M_{\mathrm{w}}$ and the grain size data (Fig. 2c). We then expect that the occurrence of earthquakes larger than $4.5 M_{\mathrm{w}}$, and related to this, the subduction mechanisms, do not exert a measurable control on the grain size in the rivers of the western Peruvian Andes.

\subsubsection{Possible threshold limits as controls on the grain size pattern}

The correlations between the grain size data and the basinscale properties (basin area, mean basin denudation rates, water shear stresses, sediment fluxes) as rather weak and unconvincing (Table 3 ). However, we recall that the $\mathrm{D}_{50}$ values record a nearly uniform pattern, with values that range between 2 and $3 \mathrm{~cm}$ along the studied western Peruvian margin. However, higher values of up to $6 \mathrm{~cm}$ are either measured in streams where mean slope angles of the bordering hillslopes in the upstream basin exceed $20^{\circ}$ (between 11 and $12^{\circ} \mathrm{S}$ ) or where water run-off values are nearly twice as large as the mean of all Peruvian streams (ranging between 10 and $40 \mathrm{~m}^{3} \mathrm{~s}^{-1}$ between 16 and $17^{\circ} \mathrm{S}$; see Fig. 3 and Table 3 ). Based on these observations, we tentatively interpret a supply control on the median grain size for the Cordillera Negra streams where slopes mediate grain size through a threshold effect. In this case, these thresholds on the basin hillslope angles are likely to be conditioned by the at-yield mechanical states of bedrock (Montgomery, 2001; Ouimet et al., 2009), where hillslopes with dip angles up to $20-25^{\circ}$ can be sustained. In these conditions, hillslopes approach a threshold at which slope angles are limited by the mechanical strength of bedrock (Montgomery, 2001; Schlunegger et al., 2013). Hillslope erosion is then mainly accomplished through mass failure processes, which dominate the supply of material to the trunk and are likely to supply more coarse-grained material to the trunk stream, as modern examples have shown (Bekaddour et al., 2013). In the same sense, a threshold response to steeper slopes has been interpreted for the pattern of ${ }^{10} \mathrm{Be}$-based denudation rates in the Andes (Reber et al., 2017) and in the Himalayas (Ouimet et al., 2009). In both cases, the relationships between denudation rates and mean basin slopes were considered to follow a non-linear diffusive mass transport model in which denudation rates are proportional to mean basin slopes for low gradients, while these relationships become non-linear for slopes approaching a critical value. Reber et al. (2017) set this critical value to $27.5^{\circ}$, but the linear relationship of their dataset breaks apart for gradients larger than 0.4, which corresponds to an angle of ca. $21^{\circ}$. We note, however, that a confirmation of this hypothesis requires data about the spatial density and frequency of landslide occurrence along the western Peruvian Andes. This dataset, however, is not available yet, and its establishment warrants further investigations.

In basins situated between 16 and $17^{\circ} \mathrm{S}$, mean basin slopes are clearly below threshold conditions, but the $\mathrm{D}_{50}$ values are twice as large as in neighbouring rivers. Interestingly, these streams have mean annual discharge values that are twice as large as the western Peruvian streams on average. Similar to the Cordillera Negra, we relate the relationships at $16-17^{\circ} \mathrm{S}$ to threshold controls. In this case, however, they are likely to be conditioned by transport. The mechanisms by which grain size can be mediated through a threshold effect upon trans- 
port are less well understood, but it has been known at least since the engineering work by Shields (1936), and particularly by Meyer-Peter and Müller (1948), which has shown that threshold conditions have to be exceeded and have a control on transport of grains in fluvial streams. As a consequence, at transport-limited conditions, sediment flux, and most likely also the caliber of the transported material, depends on the frequency and the magnitudes at which these thresholds are exceeded rather than on a mean value of water discharge (Dadson et al., 2003). This might be the reason why values of water shear stresses, which are calculated here based on the annual mean of water flux, are not strongly correlated with the $\mathrm{D}_{50}$ values (Table 3 ). However, the lack of information about discharge patterns prevents us from calculating the magnitude-frequency distribution of run-off. Nevertheless, we consider the occurrence of large peak floods for streams that capture a large portion of their waters on the Altiplano Plateau, as is the case for the Rio Ocoña and Rio Camaña. We thus tentatively assign large peak floods for these streams, which might explain the larger $\mathrm{D}_{50}$ values encountered in their gravel bars. Although highly speculative, we support our statement with the highly seasonal character of precipitation occurrence, particularly on the eastern Andean margin and the Altiplano Plateau, which is largely conditioned by the monsoonal Andean jet (see above). We note, however, that this statement warrants a high-resolution hydrological dataset for the western Peruvian streams, which is not available.

An exception from these relationships is presented by the Rio Santa (Fig. 1a) where mean annual water discharge reaches a value of almost $80 \mathrm{~m}^{3} \mathrm{~s}^{-1}$, but where the size of the $\mathrm{D}_{50}$ is low. We relate this to the possible supply-limited state of this stream, conditioned by the orogen-parallel valley of the Rio Santa between the Cordillera Blanca and the Cordillera Negra, which has acted as a subsiding graben for 5.4 Myr (Giovanni et al., 2010; Margirier et al., 2015) and which might thus have operated as a sediment trap. This interpretation is also consistent with the low ${ }^{10} \mathrm{Be}$-based catchment-averaged denudation rates measured for the Rio Santa basin, as noted by Reber et al. (2017).

Note that our inferences are largely based on the pattern of the $\mathrm{D}_{50}$ and that the consideration of the larger percentiles might add alternative views of our interpretations. However, since all percentiles are intercorrelated, as suggested by the pattern of the Pearson correlation coefficients (Table 3), we think that our general conclusions about the occurrence of thresholds upon the supply and transport of sediment will not change. Note also that either transport or supply control and related thresholds were identified by Reber et al. (2017) for their explanation of the ${ }^{10} \mathrm{Be}$-based datasets on basinaveraged denudation rates in the western Peruvian Andes. We tentatively interpret that the grain size pattern of the Peruvian streams follows these lines.

\section{Conclusions}

We present a complete dataset about grain sizes for all major rivers that are situated on the western Andean margin of Peru. We did not find any correlations to the current seismic regimes, in which a larger occurrence of earthquakes with magnitudes larger than $4.5 M_{\mathrm{w}}$ is expected to increase the supply of coarse-grained material. However, we found that the values for the $\mathrm{D}_{50}$ are nearly constant and range between 2 and $3 \mathrm{~cm}$. Exceptionally larger $D_{50}$ values of $4-6 \mathrm{~cm}$ were measured for basins situated between $11-12^{\circ} \mathrm{S}$ and $16-17^{\circ} \mathrm{S}$ where hillslope gradients are steeper than average (i.e. 20$22^{\circ}$ ), or where mean annual stream flows exceed the average values of the western Peruvian streams $\left(10-40 \mathrm{~m}^{3} \mathrm{~s}^{-1}\right)$ by a factor of 2 . We suggest that the generally uniform grain size pattern has been perturbed where either mean basin slopes or water fluxes exceed threshold conditions upon the supply and the transport of material. This might have implications for our understanding of the controls on the grain size distribution of gravel-based streams.

Data availability. All the data used in this publication are available in the tables and figures.

Competing interests. The authors declare that they have no conflict of interest.

Acknowledgements. This project is funded by the Swiss National Science Foundation (project no. 137516). We thank the associate editor Robert Hilton and editor Andreas Lang for handling the paper and the referees for their constructive comments.

Edited by: Robert Hilton

Reviewed by: two anonymous referees

\section{References}

Abbühl, L. M., Norton, K. P., Jansen, J. D., Schlunegger, F., Aldahan, A., and Possnert, G.: Erosion rates and mechanisms of knickzone retreat inferred from 10Be measured across strong climate gradients on the northern and central Andes Western Escarpment, Earth Surf. Proc. Land., 36, 1464-1473, 2011.

Allen, G. H., Barnes, J. B., Pavelsky, T. M., and Kirby, E.: Lithologic and tectonic controls on bedrock channel form at the northwest Himalayan front, J. Geophys. Res.-Earth, 118, 1806-1825, 2013.

Allen, P. A., Armitage, J. J., Whittaker, A. C., Michael, N. A., RodaBoluda, D. and D'Arcy, M.: Fragmentation model of the grain size mix of sediment supplied to basins, J. Geol., 123, 405-427, 2015.

Allen, P. A., Michael, N. A., D’Arcy, M., Roda-Boluda, D. C., Whittaker, A. C., Duller, R. A., and Armitage, J. J.: Fractionation of 
grain size in terrestrial sediment routing systems, Basin Res., 29, 180-202, 2016.

Atherton, M. P.: The coastal batholith of Peru, in: Andean Magmatism, 168-179, Birkhäuser, Boston, 1984.

Attal, M. and Lavé, J.: Changes of bedload characteristics along the Marsyandi River (central Nepal): Implications for understanding hillslope sediment supply, sediment load evolution along fluvial networks, and denudation in active orogenic belts, Geol. S. Am. S., 398, 143-171, 2006.

Attal, M. and Lavé, J.: Pebble abrasion during fluvial transport: experimental results and implications for the evolution of the sediment load along rivers, J. Geophys. Res., 114, F04023, https://doi.org/10.1029/2009JF001328, 2009.

Attal, M., Mudd, S. M., Hurst, M. D., Weinman, B., Yoo, K., and Naylor, M.: Impact of change in erosion rate and landscape steepness on hillslope and fluvial sediments grain size in the Feather River basin (Sierra Nevada, California), Earth Surf. Dynam., 3, 201-222, https://doi.org/10.5194/esurf-3-201-2015, 2015.

Bekaddour, T., Schlunegger, F., Attal, M., and Norton, K. P.: Lateral sediment sources and knickzones as controls on spatio-temporal variations of sediment transport in an Alpine river, Sedimentology, 60, 342-357, 2013.

Blissenbach, E.: Relation of surface angle distribution to particle size distribution on alluvial fans, J. Sediment. Petrol., 22, 25-28, 1952.

Bookhagen, B. and Strecker, M. R.: Orographic barriers, high-resolution TRMM rainfall, and relief variations along the eastern Andes, Geophys. Res. Lett., 35, L06403, https://doi.org/10.1029/2007GL032011, 2008.

Bourgois, J., Bigot-Cormier, F., Bourles, D., Braucher, R., Dauteuil, O., Witt, C., and Michaud, F.: Tectonic record of strain buildup and abrupt coseismic stress release across the northwestern Peru coastal plain, shelf, and continental slope during the past $200 \mathrm{kyr}$, J. Geophys. Res.-Sol. Ea., 112, https://doi.org/10.1029/2006JB004491, 2007.

Bunte, K. and Abt, S. R.: Sampling frame for improving pebble count accuracy in coarse gravel-bed rivers, J. Am. Water Resour. As., 37, 1001-1014, 2001a.

Bunte, K. and Abt, S. R.: Sampling surface and subsurface particlesize distributions in wadable gravel- and cobble-bed rivers for analyses in sediment transport, hydraulics, and streambed monitoring, General Technical Report RMRS-GTR-74. United States Department of Agriculture, Forest Service; Rocky Mountain Research Station, Fort Collings, USA, 428 pp., 2001b.

Carretier, S., Tolorza, V., Rodríguez, M. P., Pepin, E., Aguilar, G., Regard, V., and Hérail, G.: Erosion in the Chilean Andes between $27^{\circ} \mathrm{S}$ and $39^{\circ} \mathrm{S}$ : tectonic, climatic and geomorphic control, Geological Society, London, Special Publications, 399, 401-418, 2015.

Dadson, S. J., Hovius, N., Chen, H., Dade, W. B., Hsieh, M. L., Willett, S. D., and Lague, D.: Links between erosion, runoff variability and seismicity in the Taiwan orogen, Nature, 426, 648-651, 2003.

D'Arcy, M., Whittaker, A. C., and Roda-Boluda, D. C.: Measuring alluvial fan sensitivity to past climate changes using a selfsimilarity approach to grain-size fining, Death Valley, California, Sedimentology, 64, 388-424, 2017.

DeVries, T. J.: A review of geological evidence for ancient El Nino activity in Peru, J. Geophys. Res., 92, 471-514, 1987.
Dingle, E. H., Attal, M., and Sinclair, H. D.: Abrasion-set limits on Himalayan gravel flux, Nature, 544, 471-474, 2017.

Duller, R. A., Whittaker, A. C., Swinehart, J. B., Armitage, J. J., Sinclair, H. D., Bair, A., and Allen, P. A.: Abrupt landscape change post-6 Ma on the central Great Plains, USA, Geology, 40, 871874, 2012.

Fedele, J. J. and Paola C.: Similarity solutions for fluvial sediment fining by selective deposition, J. Geophys. Res.-Earth, 112, https://doi.org/10.1029/2005JF000409, 2007.

Foreman, B. Z.: Climate-driven generation of a fluvial sheet sand body at the Paleocene-Eocene boundary in north-west Wyoming (USA), Basin Res., 26, 225-241, 2014.

Foreman, B. Z., Heller, P. L., and Clementz, M. T.: Fluvial response to abrupt global warming at the Palaeocene/Eocene boundary, Nature, 491, 92-95, 2012.

Garreaud, R. D., Vuille, M., Compagnucci, R., and Marengo, J.: Present-day South American climate, Palaeogeogr. Palaeocl., 281, 180-195, 2009.

Giovanni, M. K., Horton, B. K., Garzione, C. N., McNulty, B., and Grove, M.: Extensional basin evolution in the Cordillera Blanca, Peru: Stratigraphic and isotopic records of detachment faulting and orogenic collapse in the Andean hinterland, Tectonics, 29, https://doi.org/10.1029/2010TC002666, 2010.

Haederle, M. and Atherton, M. P.: Shape and intrusion style of the Coastal Batholith, Peru, Tectonophysics, 345, 17-28, 2002.

Hancock, G. S. and Anderson, R. S.: Numerical modeling of fluvial strath-terrace formation in response to oscillating climate, Geol. Soc. Am. Bull., 114, 1131-1142, 2002.

Heller, P. L. and Paola, C.: The large-scale dynamics of grain-size variation in alluvial basins, 2: Application to syntectonic conglomerate, Basin Res., 4, 91-102, 1992.

Hjulström, F.: Studies in the morphological activity of rivers as illustrated by the river Fyris, Bulletin of the Geological Institution of the University of Uppsala, 25, 221-528, 1935.

Hoey, T. B. and Ferguson, R.: Numerical simulation of downstream fining by selective transport in gravel bed rivers: Model development and illustration, Water Resour. Res., 30, 2251-2260, 1994.

Hovius, N., Stark, C. P., and Allen, P. A.: Sediment flux from a mountain belt derived by landslide mapping, Geology, 25, 231234, 1997.

Howard, J. L.: The statistics of counting clasts in rudites: a review with examples from the upper Paleogene of southern California, USA, Sedimentology, 40, 157-174, 1993.

Huffman, G. J., Bolvin, D. T., Nelkin, E. J., Wolff, D. B., Adler, R. F., Gu, G., and Stocker, E. F.: The TRMM multisatellite precipitation analysis (TMPA): Quasi-global, multiyear, combinedsensor precipitation estimates at fine scales, J. Hydrometeorol. 8, 38-55, 2007.

Isacks, B. L.: Uplift of the central Andean plateau and bending of the Bolivian orocline, J. Geophys. Res.-Sol. Ea., 93, 3211-3231, 1988.

Keefer, D. K.: Landslides caused by earthquakes, Geol. Soc. Am. Bull., 95, 406-421, 1984.

Keefer, D. K.: The importance of earthquake-induced landslides to long-term slope erosion and slope-failure hazards in seismically active regions, Geomorphology, 10, 265-284, 1994.

Kodoma, Y.: Downstream changes in the lithology and grain size of fluvial gravels, the Watarase River, Japan: Evidence of the role 
of abrasion in downstream fining, J. Sediment. Res., 64, 68-75, 1994.

Koiter, A. J., Owens, P. N., Petticrew, E. L., and Lobb, D. A.: The behaviour characteristics of sediment properties and their implications for sediment fingerprinting as an approach for identifying sediment source sin river basins, Earth Sci. Rev., 125, 24-42, 2013.

Korup, O. and Schlunegger, F.: Rock-type control on erosioninduced uplift, eastern Swiss Alps, Earth Planet. Sc. Lett., 278, 278-285, 2009.

Korup, O. and Weidinger, J. T.: Rock type, precipitation, and the steepness of Himalayan threshold hillslopes. Geological Society, London, Special Publications, 353, 235-249, 2011.

Lisle, T. E., Iseya, F., and Ikeda, H.: Response of a channel with alternate bars to a decrease in supply of mixed-size bed load: A flume experiment, Water Resour. Res., 29, 3623-3629, 1993.

Litty, C., Duller, R., and Schlunegger, F.: Paleohydraulic reconstruction of a 40 ka-old terrace sequence implies that water discharge was larger than today, Earth Surf. Proc. Land., 41, 884-898, https://doi.org/10.1002/esp.3872, 2016.

Litty, C., Lanari, P., Burn, M., and Schlunegger, F.: Climatecontrolled shifts in sediment provenance inferred from detrital zircon ages, Western Peruvian Andes, Geology, 45, 59-62, 2017.

Macharé, J. and Ortlieb, L.: Plio-Quaternary vertical motions and the subduction of the Nazca Ridge, central coast of Peru, Tectonophysics, 205, 97-108, 1992.

Marcus, W. A., Ladd, S. C., Stoughton, J. A., and Stock, J. W.: Pebble counts and the role of user-dependent bias in documenting sediment size distributions, Water Resour. Res., 31, 2625-2631, 1995.

Margirier, A., Robert, X., Audin, L., Gautheron, C., Bernet, M., Hall, S., Simon-Labric, T.: Slab flattening, magmatism, and surface uplift in the Cordillera Occidental (northern Peru), Geology, 43, 1031-1034, 2015.

McLaren, P. and Bowles, D.: The Effects of Sediment Transport on Grain-Size Distributions, J. Sediment. Petrol., 55, 457-470, 1985.

McNulty, B. and Farber, D.: Active detachment faulting above the Peruvian flat slab, Geology, 30, 567-570, 2002.

McPhillips, D., Bierman, P. R., and Rood, D. H.: Millennial-scale record of landslides in the Andes consistent with earthquake trigger, Nat. Geosci., 7, 925-930, 2014.

Meyer-Peter, E. and Müller, R.: Formulas for bed-load transport, in: IAHSR 2nd meeting, Stockholm, Appendix 2, IAHR, 1948.

Montgomery, D.: Slope distributions, threshold hillslopes, and steady-state topography, Am. J. Sci., 301, 432-454, 2001.

Montgomery, D. R., Balco, G., and Willett, S. D.: Climate, tectonics, and the morphology of the Andes, Geology, 29, 579-582, 2001.

Mukasa, S. B.: Zircon U-Pb ages of super-units in the Coastal batholith, Peru: Implications for magmatic and tectonic processes, Geol. Soc. Am. Bull., 97, 241-254, 1986.

Nocquet, J. M., Villegas-Lanza, J. C., Chlieh, M., Mothes, P. A., Rolandone, F., Jarrin, P., and Martin, X.: Motion of continental slivers and creeping subduction in the northern Andes, Nat. Geosci., 7, 287-291, 2014.

Noury, M., Bernet, M., Schildgen, T. F., Simon-Labric, T., Philippon, M., and Sempere, T.: Crustal-scale block tilting dur- ing Andean trench-parallel extension: Structural and geo- thermochronological insights, Tectonics, 35, 2052-2069, 2016.

Ouimet, W. B., Whipple, K. X., and Granger, D. E.: Beyond threshold hillslopes: Channel adjustment to base-level fall in tectonically active mountain ranges, Geology, 37, 579-582, 2009.

Paola, C. and Seal, R.: Grain size patchiness as a cause of selective deposition and downstream fining, Water Resour. Res., 31, 13951407, 1995.

Paola, C., Heller, P. L., and Angevinet, C. L.: The large-scale dynamics of grain-size variation in alluvial basins, 1: Theory, Basin Res., 4, 73-90, 1992a.

Paola, C., Parker, G., Seal, R., Sinha, S. K., Southard, J. B., and Wilcock, P. R.: Downstream fining by selective deposition in a laboratory flume, Science, 258, 1757-1760, 1992b.

Parker, G.: Selective sorting and abrasion of river gravel. 1: Theory, J. Hydraul. Eng., 117, 131-147, 1991.

Parker, R. N., Densmore, A. L., Rosser, N. J., De Michele, M., Li, Y., Huang, R., and Petley, D. N.: Mass wasting triggered by the 2008 Wenchuan earthquake is greater than orogenic growth, Nat. Geosci., 4, 449-452, 2011.

Pearson, K.: Notes on regression and inheritance in the case of two parents, P. Roy. Soc. London, 58, 240-242, 1895.

Ramos, V. A.: The tectonic regime along the Andes: Present-day and Mesozoic regimes, Geol. J., 45, 2-25, 2010.

Rasband, W. S.: ImageJ, US National Institutes of Health, Bethesda, Maryland, USA, available at: http://imagej.nih.gov/ij/ (last access: September 2013), 1997-2016.

Reber, R., Delunel, R., Schlunegger, F., Litty, C., Madella, A., Akçar, N., and Christl, M.: Environmental controls on 10Be-based catchment averaged denudation rates along the western margin of the Peruvian Andes, Terra Nova, 1-12, https://doi.org/10.1111/ter.12274, 2017.

Regard, V., Saillard, M., Martinod, J., Audin, L., Carretier, S., Pedoja, K., and Hérail, G.: Renewed uplift of the Central Andes Forearc revealed by coastal evolution during the Quaternary, Earth Planet. Sc. Lett., 297, 199-210, 2010.

Reuter, H. I., Nelson, A., and Jarvis, A.: An evaluation of voidfilling interpolation methods for SRTM data, Int. J. Geogr. Inf. Sci., 21, 983-1008, 2007.

Rice, S. and Church, M.: Grain size along two gravel-bed rivers: Statistical variation, spatial pattern and sedimentary links, Earth Surf. Proc. Land., 23, 345-363, 1998.

Robinson, R. A. and Slingerland, R. L.: Origin of fluvial grain-size trends in a foreland basin: the Pocono Formation on the central Appalachian basin, J. Sediment. Res., 68, 473-486, 1998.

Schildgen, T. F., Hodges, K. V., Whipple, K. X., Reiners, P. W., and Pringle, M. S.: Uplift of the western margin of the Andean plateau revealed from canyon incision history, southern Peru, Geology, 35, 523-526, 2007.

Schlunegger, F., Norton, K. P., and Caduff, R.: Hillslope processes in temperate environments, in: Treatise on Geomorphology, edited by: Shorder, J. F., San Diego, Academic Press, 7, 337-345, 2013.

Schumm, S. A. and Stevens, M. A.: Abrasion in place: a mechanism for rounding and size reduction of coarse sediments in rivers, Geology, 1, 37-40, 1973.

Sébrier, M., Mercier, J. L., Macharé, J., Bonnot, D., Cabrera, J., and Blanc, J. L.: The state of stress in an overriding plate situated 
above a flat slab: The Andes of central Peru, Tectonics, 7, 895928, 1988

Shields, A.: Anwendung der Ahnlichkeitsmekanik und der Turbulenzforschung auf die Geschiebebewegung, Mittelung der preussischen Versuchsanstalt für Wasserbau und Schiffbau, 26, Berlin, 1936.

Sneed, E. D. and Folk, R. L.: Pebbles in the lower Colorado River, Texas a study in particle morphogenesis, J. Geol., 66, 114-150, 1958.

SNIRH: Sistema Nacional de Informacion de Recursos Hidricos, available at: http://snirh.ana.gob.pe/consultasSnirh/ ConsHidrom2.aspx, last access: May 2017.

Steffen, D., Schlunegger, F., and Preusser, F.: Late Pleistocene fans and terraces in the Majes valley, southern Peru, and their relation to climatic variations, Int. J. Earth Sci., 99, 1975-1989, 2010.

Sternberg, H.: Untersuchungen über längen-und Querprofil geschiebeführender Flüsse, Z. Bauwes., 25, 486-506, 1875.

Surian, N.: Downstream variation in grain size along an Alpine river: analysis of controls and processes, Geomorphology, 43, 137-149, 2002.
Trauerstein, M., Norton, K. P., Preusser, F., and Schlunegger, F. Climatic imprint on landscape morphology in the western escarpment of the Andes, Geomorphology, 194, 76-83, 2013.

Vidal, J. C.: Geologia de los cuadrangulos de Huambo y Orcopampa, v 46. Instituto Geologico Minero y Metalurgico, Lima, 1993.

Whittaker, A. C., Cowie, P. A., Attal, M., Tucker, G. E., and Roberts, G. P.: Bedrock channel adjustment to tectonic forcing: Implications for predicting river incision rates, Geology, 35, 103-106, 2007.

Whittaker, A. C., Attal, M., and Allen, P. A.: Characterising the origin, nature and fate of sediment exported from catchment perturbed by active tectonics, Basin Res., 22, 809-828, 2010.

Wittmann, H., von Blanckenburg, F., Kruesmann, T., Norton, K. P., and Kubik, P. W.: Relation between rock uplift and denudation from cosmogenic nuclides in river sediment in the Central Alps of Switzerland, J. Geophys. Res.-Earth, 112, https://doi.org/10.1029/2006JF000729., 2007. 